\title{
Race as a weapon: defending the colonial plantation order in the name of civilization, 1791-1850
}

\author{
Consuelo Naranjo Orovio ${ }^{1}$ and José F. Buscaglia ${ }^{2}$ \\ ${ }^{1}$ Instituto de Historia-CSIC, Calle Albasanz 26-28. 28037 Madrid. Spain \\ ${ }^{2}$ Northeastern University, 220 Renaissance Park, 1135 Tremont St. Boston MA 02120 \\ e-mail: chelo.naranjo@cchs.csic.es; j.buscaglia@neu.edu
}

Submitted: 10 March 2015. Accepted: 20 July 2015

\begin{abstract}
The object of this study is to analyze the use and adaptation of racialist ideology in the Afro-Hispanic Antilles following the start of the Revolution of Saint-Domingue in 1791, as it evolved to justify and reinforce plantation slavery and served to reinstitute and police the color line that was the central ideological premise supporting the economy of exchange and exploitation in the world of Atlantic coloniality. The renewed stigmatization of the racialized types in Creole population aimed to limit the echoes of the revolution against the plantation and it was an attempt to dismiss its political significance as a movement of self-emancipation and decolonization. The fear promoted by the colonial authorities, the planter class and Creole intellectuals, liberal and otherwise, aimed to establish a delicate balance between terror and profits wanting to justify the continuation of plantation slavery through the purposeful resemantization of the ideological tandem civilization/barbarity based on a racialized reading of history that championed European immigration and the systematic reduction of the population of Afro-descendants.
\end{abstract}

KEYWORDS: Saint-Domingue; Haiti; Santo Domingo; Cuba; Puerto Rico; Spain; slavery; race; racialism; civilization; barbarity; fear; terror; genocide.

Citation / Cómo citar este artículo: Naranjo Orovio, Consuelo y Buscaglia, José F. (2015). "Race as a weapon: defending the colonial plantation order in the name of civilization, 1791-1850". Culture \& History Digital Journal, 4 (2): e 012. doi: http://dx.doi.org/10.3989/chdj.2015.012.

RESUMEN: La raza como arma: la defensa del orden colonial de plantación en nombre de la civilización, 17911850.- El objetivo de este estudio es analizar el uso y adaptación de la ideología racialista en las Antillas afrohispanas tras el estallido de la Revolución de Saint-Domingue en 1791 a medida que ésta fue evolucionando con el fin de justificar y afianzar la plantación esclavista. La continua estigmatización de los tipos racializados en la población criolla contribuyó a enmudecer los ecos de la revolución de los esclavos, especialmente la gran relevancia que en términos políticos tuvo el movimiento de auto-emancipación y descolonización. El miedo impulsado por las autoridades coloniales, los hacendados esclavistas y los intelectuales (liberales o no) procuró mantener un balance delicado entre el terror y las ganancias con el objetivo de intentar justificar la continuidad de la esclavitud mediante la resemantización deliberada del tándem ideológico civilización/barbarie. Dicha resemantización estaba basada en una interpretación racializada de la historia que buscó promover la inmigración de europeos y la reducción sistemática de la población de afrodescendientes.

PALABRAS CLAVE: Saint-Domingue; Haiti; Santo Domingo; Cuba; Puerto Rico; España; esclavitud; raza; racialismo; civilización; barbarie; miedo; negro; terror; genocidio.

Copyright: (C) 2015 CSIC This is an open-access article distributed under the terms of the Creative Commons AttributionNon Commercial (by-nc) Spain 3.0 License. 
The principal intent of this study is to show the ways in which racialist discourse was manipulated and strengthened following the Saint-Domingue Revolution of 1791 in an attempt to undo the political victories of self-emancipation, colonial liberation and state formation that resulted in the proclamation of the Republic of Haiti in 1804. The ideology of racialism that grew out of the Columbian experience and was significantly reinforced over three centuries by religious, legal, political and eventually pseudo-scientific arguments was literally disarmed in the battlefields of Hispaniola and fully deauthorized by the constitution drafted by the Central Assembly of the French colony of Saint-Domingue and signed in Cap Français by Toussaint Louverture on July 3, 1801. That document, which official Euro-centric narratives have extirpated from the historical record of human progress, outlawed slavery and proclaimed the legal equality of all citizens. Article 3 declared, "Henceforth, all men are born, live and die free and French."1 Nowhere in the seventy-seven articles of the document is there a single mention of "Whites", "Blacks", "Mulattoes" or any other racialist term.

\section{THE UNDOING OF THE EUROPEAN IDEAL AND THE RISE OF THE MODERN BARBARIAN}

The "events" of Saint-Domingue shook the very foundations of the colonial order and the ideological basis of the Old Regime in the Atlantic World that privileged the European male subject as the ideal man (Buscaglia Salgado, 2003). As many have pointed out, the revolution against the plantation in Hispaniola marked the beginning of a new era in human progress (Geggus, 2001, 2002, 2010; Dubois, 2004; Garrigus, 2006; Geggus \& Fiering, 2008). Indeed, Louverture and the movement he led used both sword and pen to outmaneuver the military and political elites of Europe in the Age of Revolution. First Consul Napoleon Bonaparte was outraged by Loverture's constitution, considering parts of it to be an affront to the dignity and sovereignty of the French people (Schoelcher, 1889). To Bonaparte, who proved to be an avowed racist, particularly in his dealings with Alex Dumas (Reiss, 2012), a highly decorated French general born in SaintDomingue, the former slaves of Hispaniola not only had taken their freedom in a manner illegal by turning against their "rightful" masters and abandoning the plantations; they had also committed a major affront to France by declaring themselves to be French citizens in full standing and claiming all the Rights of Man.

Bonaparte's outrage, and his need to finance his armies in Europe with the profits from Dominican sugar, led him to dispatch thirty thousand elite troops to the colony under the command of his brother-in-law, Victor Emmanuel Leclerc, with orders to submit the rebels and reestablish slavery. The full weight of this contradiction to French revolutionary dogma would not be felt until a year later, in March 1802, when Louverture ordered JeanJacques Dessalines to take and defend at all costs the fortress of Crête-à-Pierrot form the advance of the great force that Bonaparte had sent to Saint-Domingue. A scramble ensued as both armies raced to the fort. Dessaline's men got there first, jumping into the dry moat and firing back at Leclerc's troops who were now in the open. In his memoirs, the French general Pamphile de Lacroix left a telling record of the episode: "From that moment we were unmasked, the redoubt fired back with all it had, and instantly everything about us was turned around" (Lacroix, 1995: 331). Even though Dessaline's troops were completely surrounded and massively outnumbered, Lacroix feared that the French did not have control of the situation. He wrote: "We do not inspire any moral terror, and that is the worst possible thing that could happen to an army" (Lacroix, 1995: 332).

Things got worst for the elite republican troops that had come to do the work of the Marechaussee, the feared slave-catching battalions. Dessaline's men put up the fiercest resistance. French casualties began to rise and the corpses could not be buried fast enough. As Leclerc's men resorted to burning the bodies of their fallen comrades an unbearable stench filled the atmosphere. Death was literally in the air. Yet, men were not the only casualties in those fateful Ides of March in the tropics. Lacroix recalls how every night the elite troops of the First Consul could hear singing coming from behind the walls of the fortress. The defenders of Crête-à-Pierrot were chanting the anthems of the French revolutionary vanguards, the Ça Ira and the Marsellaise among them. His reflections are quite telling as they reveal the anxieties of soldiers who thought themselves to be the liberators of Humanity and who now faced death far away from home doing double duty as slave-catchers:

\footnotetext{
While we were laying siege to the fort, we could hear the enemy singing patriotic verses to the glory of France. In spite of the indignation we felt at the atrocities committed by the Blacks, those songs troubled us. Our soldiers looked at us dumbstruck as if saying: "Could reason be on the side of our barbarous enemies? Are we no longer the soldiers of the Republic? And have we become the servile instruments of politics? (Lacroix, 1995: 333).
}

Lacroix was not precise enough when he pointed to the troubling nature of the music coming from the fort. It was not the songs that troubled Leclerc's men but the mouths that were uttering the words. It seemed that the defenders of Crête-à-Pierrot had not only been able to understand revolutionary doctrine but were now carrying their ideals to a higher state of enunciation. The elite troops of the First Consul and the very idées napoléoniennes had been unmasked and turned around. At that very moment, having been left speechless and dethroned as the ideal subject of modernity, Lacroix was one of the first European chroniclers to conjure and bring forth in the most direct manner the fundamental thesis of the discourse that would bridge the repressive and genocidal policies set forth in the old colonial slave codes with the new racialist discourse of bourgeois modernity and 
imperial nationalisms. As in the quote above, the socalled "Blacks" would be depicted not as liberators and revolutionaries but as barbarous enemies who commit the worst atrocities. Thus started a defamation campaign that would become the first major propaganda war in modern times. The etchings from Saint-Domingue propagated all over Europe and North America depicted the free men and women of Saint-Domingue as vicious murderers and rapists who were nothing more than beasts and even cannibals.

\section{IN THE NAME OF HAPPINESS THE SPANISH PLANTERS ALSO CRY WOLF}

French propaganda reached the Spanish colonies of Cuba and Puerto Rico with the first refugees from SaintDomingue and it immediately informed colonialist discourse as well as some of the first major enunciations of proto-nationalist sensibilities and concerns. The news of the downfall of the French colony was received with joy by the representative of Havana's town hall in Madrid, Francisco de Arango y Parreño who immediately set himself to work on outlining the resources needed to develop the economy of the Spanish colony, a proposal that would have been unthinkable prior to the slave uprising when, in comparison with the French colony, Cuba was "an atom next to a colossus" (González-Ripoll, 2004: 9-81; Gomariz, 2004). Indeed, a similar initiative under the aegis of a proposed "Spanish Negro Code" was officially tabled by Madrid a decade earlier in the colony of Santo Domingo. Arango y Parreño was able to envision the benefits that Cuba would derive, informing the authorities in Madrid in his "Report to His Majesty pertaining to the slave rebellion in the French colony of Saint-Domingue" of November 20, 1791: "It is an opportunity and a way to give the agriculture of the islands the advantage and primacy over the French" being "our duty to persevere and to make the most of our neighbor's time of inaction" (Arango y Parreño, 1952, I: 112).

Arango y Parreño's vision and, indeed, his understanding of the measures that would need to be put in place in order to launch the full development potential of the colonies, were not that visionary. They were simply copied from what he had seen in his recent travels through the English sugar islands. A year later, in 1792, he had become the principal spokesperson for the planters outlining their demands in a detailed report that would become a key reference work in discussions of Cuban political economy. "There is no doubt that the hour of happiness is here", he wrote in the "Discourse on the agriculture of Havana and on the means to promote it" (Arango y Parreño, 1952, I: 134). The essay, that mentions the events in Saint-Domingue only in passing, labeling them as catastrophic, focused on the means to secure the happiness of the colony by means of achieving all potentiality through the development of its agriculture and prophesizing that Cuba soon would become one of the main centers of sugar production in the world. To achieve this, he argued that it would be necessary to introduce a larger number of enslaved Africans to work the fields. Earlier that same year of 1792 he had obtained approval in Madrid for his request of 1789 to bestow upon the port of Havana the royal concession for the open commerce in slaves.

His words echoed the recommendations made by Alejandro O'Reilly following his visit to the island in 1763 and published a year later in his Description of the island of Cuba. O'Reilly had been sent by the Crown, soon after the city was reclaimed from the English, to survey the needs and resources of the overseas territories and to report on the state of their defenses in advance of a plan for their strengthening and modernization. Looking around he quickly understood that the key to the generation of wealth in the region was the cultivation of sugar with slave labor. Thus his recommendations included the increase and unrestricted importation of slave laborers under favorable tax regimes and lifting all bans on commercial contracts with foreigners from friendly nations.

By November of 1808 Arango y Parreño was celebrating the success of his initiatives in the "Testimony to the Counselor on the report ordered by the Havana Consulate concerning the most convenient ways to bring the agriculture and commerce of the Island out of the troubles they suffer": "we were flying high with the opportunities that the fall of Saint-Domingue presented to us [...] and the timely support of our wise government" (Arango y Parreño, 1952, II: 18). The authorities in Madrid and Havana all agreed that these were chances that no interested party could afford to miss.

The amazing profits made on sugar turned the trade in slaves into the principal commercial activity under a state-sponsored culture of fear that was carefully managed and promoted. Sugar and slavery became an inseparable tandem in the works of theorists and politicians alike who saw in the earlier models of the English sugar islands, as furthered refined in the French colonies, the most profitable colonial enterprise. Soon, slavery would be seen in political terms as the lynchpin that secured the status quo and the very social order of the colonial system. In the Spanish Antilles the threat of slave revolt real, imagined or fabricated as in the Massacre of $L a$ Escalera in Cuba (1844) — became the favorite ideological weapon in a complex mechanism of social control. The authorities and the elites in Cuba and Puerto Rico learned to navigate skillfully between fear and profits. This required putting in motion two otherwise contradictory projects. On the one hand was the promotion and expansion of all activities relating to slave trading. On the other, policies were set in place to promote emigration of "White" colonists and laborers from Europe as a way of keeping the "racial balance" by avoiding further Africanization of the societies.

The proposed increase in population and the consequent "racial mixing" that would result forced the authorities to rely heavily on the stipulations of the old slave codes. It was obvious that there could be no economic growth without constant policing to assure social stability. The Spanish Negro Code of 1784, much debated but 
never fully implemented, divided colonial societies along a continuum with four intermediate stations between the extremes of (free)"White" and "Black"(slave). Described by a movement of "racial cleansing" or blanqueamiento ("Whitening") these were: "Brown", "Terceroon", "Quarteroon" and "Mestizo". In this way, for example, according to Chapter 3, Law 6, "Black" and "Brown" subjects were strictly limited to work in agricultural production as field laborers, free or enslaved. The color line was placed between the "Brown" and "Terceroons" who, together with "Quarteroons" and "Mestizos" were entitled to receive an education although never in the company of "Whites". Penal laws would make this division clearer. Law 9 in that same chapter dealing with "The Police" stipulated that a "Terceroon", "Quarteroon" or "Mestizo" convicted of attacking a "White" person would be condemned to six years in jail. For the same offense, a "Black" or "Brown" individual would have a hand nailed to a board and subsequently sawed off.

Still everything had changed after the defeat of the French, English and Spanish armies in Hispaniola at the hands of the rebels and the subsequent signing of Louverture's Constitution in 1801. Continued enforcement of the old "Negro codes" once a significant number of former slaves had freed themselves, abolishing slavery fully and forever while claiming the Rights of Man and of the Citizen, required a more thorough and sophisticated ideological justification. Thus a new set of theories emerged to defend the idea of the inferiority of "Blacks" as most barbarous in relation to the "civilized Whites". Here again, the Spanish planters and colonial authorities borrowed heavily from the discourse and iconography of French propagandists like Lacroix.

\section{FOMENTING THE "FEAR OF BLACKS" WHILE DISMISSING THE LOUVERTURIAN IDEALS}

In his letter to the Spanish king of November 20, 1791 Arango y Parreño pointed to the need to curtail the spread of what soon would become known as "the ideas of Toussaint the Black". ${ }^{2}$ He pointed to the possibility that this could happen even "if no insurgents come over (to Cuba) spreading the doctrine of insurrection that comes out of the mouths of these apostles of the devil. The people of Havana fear this possibility and are taking all necessary precautions" (Arango y Parreño, 1952, I: 110). In very few words Arango y Parreño was spreading fear of the racialized "Other" while championing the need for order and control. There was almost no need to make any direct allusions to Saint-Domingue. Neither was it necessary to mention the slaves or to speak of "Blacks" as the notion of insurrection in the islands could only point in one direction. Ideological contamination among the laboring classes was a real threat to the Spanish planters who saw "apostles of the devil" in those who spread the revolutionary ideals of freedom and equality in colonies where the main economic activity had depended on the strictest division of labor along racialist demarcations.
For the Spanish planters it was time to fight fire with fire. Thus emerged the so-called "miedo al negro" or "fear of Blacks", an ideological formulation that came to justify the most severe political repression in the colonies. It was also a way to hide the evidence of the real terror behind the policies that would ensue by symbolically turning the colonizers and slavers into the victims of what otherwise had been and continued to be promoted in the Spanish colonies as the road to full happiness through continued and reinvigorated slavery. Just as it was not necessary to speak directly of the culprit in the spreading of revolutionary ideals, Arango y Parreño's calls for the most repressive measures are also rather veiled and always hidden behind the promises of happiness, bountifulness and fulfillment for the "people of Havana". In his "Discourse on Agriculture" of 1792 he prescribed heavy doses of prevention, caution and discipline to avoid the spread of the insurrection since "the tranquility of all my countrymen and the full enjoyment of all the happiness coming to them hanged by a threat: the continued subjection and patience with a beehive of barbarous men" (Arango, 1952, I: 149).

That busy and poisonous beehive is here the opposite of the flourishing and peaceful plantation order envisioned by the Havana planters. Yet something more complex is at play in this statement. The former slaves had freed themselves and were burning the plantations of Hispaniola to the ground in an attempt to avoid a forced return to servitude. Yet, under the Louverturian ideals they were about to abolish not only slavery but race itself. That ideological manipulation would flood the engine room of the colonial plantation system and society to effectively deactivate the very meaning of "Black" or "negro" as a synonym of slave. Thereafter the question would be: what were the authorities to do with people who refused to see themselves as "Blacks" in a society where all "Blacks" were not slaves but all slaves were "Black"?

The solution was rather simple though not perfectly logical. Henceforth those formerly called "Black" would be described as barbarians, justifying slavery in the name of civilization. Yet, there was no plan to "civilize" the "Black barbarians". As we will see, in the long term, the plan was rather to get rid of them altogether. Following the formal enunciation of the Louverturian ideals in the Constitution of 1801 , the sponsors of the plans for the happiness of Cuba would soften their rhetoric and most precautionary warnings relating to the ideological instrument of "the fear of Blacks" and its genocidal program making use of the romantic sensibilities en vogue. In his "Report to the Commission from Santo Domingo by Francisco de Arango y Parreño" of July 17, 1803, the spokesman for the planters bemoaned: "the quill falls from my hand when I attempt to comment on the sad picture that presently can be made of what until very recently was the most flourishing and wealthy colony in the world" (Arango, 1952, I: 348). Detached from its program of terror, it seemed that the programmatic imperatives for the "people of Havana" and the authorities in Madrid was not just a moral choice relative to the 
progress of human enterprise in the tandem civilization/ barbarity but an aesthetic election between sadness and happiness. Such was the main act of the Cuban plantation circus.

Back in Spain the propaganda machine was searching for the promise of a well managed "fear of Blacks" as an instrument to achieve perfect social balance and the full productive potential of the colonies. In November 1791 the Gaceta de Madrid newspaper published reports of arson and killings of "Whites" perpetrated by "Black" rebels. The press, the reports from the foreign consuls, the refugees from Saint-Domingue and from those fleeing the invasion of the neighboring Spanish colony of Santo Domingo by the army of Louverture, as well as from the agents of the merchants houses, were all corroborating the accounts of horror and terror in all the colonies where the revolutionary sentiment had taken hold.

Clearly, the very fact that the revolution against the plantation - soon to become also an anti-colonial warwas spreading rapidly throughout the region meant that there was another version of the same events and that, for a very significant sector of the population of the islands and the mainland the Louverturian ideals inspired a great deal of admiration and hope, moving many to pledge support and rise up (Ferrer, 2004: 179-231). For them it was justice and the possibility of full equality as citizens, not profit, that signaled the way to happiness: to be fully French and never again "Black" was the reason that informed their enterprise.

Still the news reaching Madrid continued to raise alarm painting a picture of anarchy and chaos. The belief that the colonies could fall under the control of the insurgents helped the authorities to take a strong stand in defense of the "civilized world". On January 28, 1801 the Captain General of Caracas, Manuel de Guevara Vasconcelos, warned the king against the great harm that could come to "civilized nations" ${ }^{3}$ should they fail to act decisively against the insurgents. A year later he would continue to warn against the nefarious consequences that the revolt of the "Blacks" in Guadeloupe could have on Spain. Yet, this time he was not just engaging the discourse of fear and paranoia but also describing how "the rule of the Black Toussaint Louverture continues to spread as he becomes a true sovereign with his latest Constitution and proclamations". ${ }^{4}$ This is a clear acceptance that the Louverturian ideals were not only spreading through wars of devastation against the plantation but also by the seduction of the sophisticated political structure of a new state of law in the Antilles that was quickly becoming a real alternative to the colonial order and its genocidal ways. As with Lacroix and almost at the same time, Vasconcelos found himself in a difficult predicament. Could it be possible that the otherwise barbarous enemies could have reason on their side? If that were the case, would that not make them equally or even more civilized than the revolutionary elites or the courtiers of Europe, thus placing Louverture, as a true sovereign, in the same sphere as the First Consul or the King of Spain?

\section{FROM "BLACK" AS SLAVE TO "BLACKS" AS MODERN BARBARIANS}

In order to correct such ideological inconsistencies the specter of the slave codes was conjured to delegitimize the revolution and its leaders as being outside of all legal regimes. Regardless of whatever laws they may have put forth, they had broken the first commandment of the plantation colony that required, above all things, absolute submission to their master. Thus, as a "Black" and a slave, Louverture had conducted himself and his people in a manner that was nothing short of "criminal". 5 Through this act of disobedience they had effectively fallen from grace. In other words, the moment they turned against their master and fled the plantation they placed themselves outside of civilization becoming a sort of modern barbarians. This act of disobedience and the ideological manipulations that would attempt to justify their re-enslavement, moved Louverture and his people away from human form and ever closer to the beasts in the annals of modern political discourse. Through this reverse logic the seventyseven articles of Louverture's constitution and the hundreds of edicts that he issued, all written in the King's French, were nothing short of mumbo jumbo.

This attempt to devoid the Louverturian ideals of all gravity by extricating them from all social context had its representative embodiment in Chapter 3, Law 9 of the Spanish Negro Code. In this, the first major campaign of defamation of modern propaganda, Louverture's constitution had been nailed on a board and subsequently cut off from the body politic. Yet, by that same logic, if the barbarous "Blacks" were incapable of upholding any civilized ideals they should not have been blamed for the criminal acts they committed in the name of a freedom to which they were not entitled and under the banner of Liberty as a concept they were incapable of understanding. This point of reason did not elude certain sophisticated observers who, defending the plantation, its slave codes, the colonial institutions and, of course, the empire, went as far as blaming the planters for the entire debacle. In the end, it seemed to some as if the "barbarous" reaction of the rebels was in some way the consequence of the less than prudent demeanor of some masters who spoke of freedom and Liberty in front of their slaves: The ideas of freedom grew and those less than prudent
settlers who called for revolution in their serpent-infest-
ed soil did not understand that, in a country that is held
together only by the slaves, to destroy the prestige that
was the basis of all their power was to deal a mortal
blow to their interests. To give their slaves the danger-
ous example of insubordination, pronouncing the words
of freedom and liberty, was to light with their own
hands the fire that devoured their properties (Marlés,
1845: 254-255).

Yet this type of accusation falls into a circular logic from which it needs to be pulled back by arguing that, since the slaves, on account of being "Black", were incapable of reason and understanding the liberal masters were never 
out of place when talking politics in their presence. Still none of the discursive levity that served to defend the colonial plantation system can begin to explain why the women and men of Crête-à-Pierrot sang the French revolutionary anthems with great pride and joy while awaiting certain death at the hands of Bonaparte's troops at sunrise. Faced with the fact, chronicled by Lacroix, that the First Consul's troops no longer inspired any moral terror on the sons and daughters of Liberty who defended the fortress, the promotion of the "fear of Blacks" was born out of the realization of being on the wrong side of progress defined at the time as the pursuit of happiness. Once the former slaves had declared themselves to be French, that is free women and men with full citizenship rights, they irreparably had ceased to be "Blacks" just as the French had irreversibly ceased to be subjects of the king on January 21, 1793 when the blade of the guillotine cut through Louis XVI's neck dumping his head into a bucket.

\section{PROFITS AND FEAR AS A DELICATE BALANCING ACT IN THE CUBAN CIRCUS}

Yet, in the Spanish colonies, the authorities and the local elites saw a window of opportunity open before their eyes. None must have had any delusions about the risks involved and, as revolution spread from the islands to the mainland, few would have argued that, regardless of the magnificent profits to be made if all went according to Arango y Pareño's plans, the days of planation slavery were numbered. The keys to the success of the project was to "avoid contagion" of the Louverturian ideals and to perfect the colonial reign of terror by promoting the "fear of the Blacks".

There was no question in the eyes of the Spanish authorities that the republican doctrines were spreading fast and reaching the coasts of the mainland where, between 1794 and 1799 there were movements and uprisings in Curaçao, Margarita Island, Caracas, Coro, Maracaibo, la Guaira and Cartagena. Their reports are filled with confiscated documents and proclamations from the revolutionaries in Saint-Domingue, Guadeloupe and Martinique including the "Extract from the Manifesto that the General Convention in Paris Presents to all Nations". ${ }^{6}$ Before the century was over the colonial authorities also had in their possession drawings with flag designs ${ }^{7}$ and lyrics for anthems such as the "American Song" proving that, contrary to prevailing neocolonial and "neo-Bolivarian" versions of national histories, the movement of independence was originally inspired by the Revolution of SaintDomingue when not directly led by Louverture, Dessalines and Alexandre Pétion. Far from dismissing Louverture's edicts and proclamations as the work of barbarians, the authorities in Caracas showed real concern at the way the ideals of "Toussaint the Black" moved people to action and served to fuel insurrectionary movements that seem ever more organized and concerted. With the proclamation of the Republic of Haiti in 1804 the "dangers of the spread of the doctrines of the island" became ever more clear to the authorities in Caracas where a copy of Dessalines' "Speech on Freedom" had been confiscated. ${ }^{9}$
The Spanish authorities acted decisively and without delay to stop the spread of the "doctrines of the island". Numerous initiatives were taken during the course of the century including the laws against runaways, the prohibition of the introduction of slaves who were not African born, the limitations on freedom of movement of both slaves and the peasantry, the denial of entry into the colonies of most persons from Hispaniola, the bans on trade with rebel territories, the strengthening of punitive laws concerning conspiracy and sedition, the bans on freedom of assembly and the disbandment of the "Colored" regiments. Still, one thing was to avoid contagion and quite another was to bet on a renewed vision of plantation slavery as the economic engine of progress in the midst of a massive revolution for freedom and equality in the islands and beyond. Thus, Arango y Pareño's vision to promote the development of "agriculture" in Cuba required proper ideological justification beyond the merely mundane mercantile considerations.

That sanction came from the colonial Church five years after the publication of his "Discourse on the agriculture of Havana" and three years before the proclamation of Louverture's constitution. Even though the war was raging in the neighboring colony, a priest in Havana was able to enunciate clearly and in the most nonchalant manner the fundamental reason justifying the use of slave labor as the economic engine that would guarantee the happiness of Cuba. Published in 1797, the Explanation of the Christian Doctrine Adapted to the Mental Capacity of the Africanborn Slaves predicated that "It is nearly the general opinion that Blacks cannot understand Christian doctrine, and that they are not even able to speak what they are taught" (Duque de Estrada, 2006: 39). The violence in the boldness of the statement was a promise to hold the color line and to protect the Ancien Régime at all cost. As in the English and French colonies before, it was now the turn of the Spaniards - in Madrid and in the islands - to institute plantation slavery on a large scale following a movement that was not merely criminal but also nothing short of genocidal.

In ideological terms the need to justify Arango y Parreño's vision of a blossoming Cuba called for the erasure of all traces of the reign of terror in plantation societies in favor of the propaganda machine built to maintain social order through the "fear of the Blacks" as savages bent on murdering the "Whites". In 1804 a book, translated from the French and published anonymously in Mexico City entitled Life of J. J. Dessalines, Leader of the Blacks in Saint-Domingue, leaves no room for ambiguity when presenting the "primitive Blacks" as the civilizational antithesis of the "civilized" European subject:

[...] we need only imagine one hundred thousand almost savage men used to committing of all sorts of atrocities, destroying and leaving nothing in their path, using the darkness of night to their advantage to fall upon the placid and unsuspecting settlers like fierce tigers and lions. Such was the movement that took place on the North of the island of Saint-Domingue in August of 1791 (Anonymous, 1806: 30). 
Erasing the terror of the plantation regime by shifting the blame for the violence of the revolution against it to the former slaves, that is, blaming the victims for their own victimization, was not just a crude and roundabout way to enable the continuation and reinvigoration of what Louverture's constitution had rendered indefensible. To be sure this would be the way to justify not only the last century of Spanish colonial exploitation in the Antilles but also the ideological underpinning of various competing currents in Cuban and Puerto Rican nationalist discourses. Above all, blaming the "Blacks" for their lot as slaves given the savage acts they had, supposedly, committed in Saint-Domingue, was not only a way of erasing the highest achievements of their revolutionary movement. It would also be a way of hiding the truly genocidal movement of the plans being put forth for the "repopulation" of Cuba and Puerto Rico.

Regardless of the various stands concerning slavery and the slave trade, most Spaniards in Cuba, Peninsular as well as Creole, agreed on the need to promote the growth of the European population in the island. Faced with the growing panic that resulted from the official and popular promotion of the "fear of Blacks", most Spaniards and foreigners in the island saw European immigration as a safeguard against revolution. But the true genocidal movement implicit in the ideological manipulation of blaming the victim by characterizing "Blacks" as savages resided in the silence kept by all except the most outspoken with regards to the ultimate consequences of putting two and two together. To be clear, the tandem that coupled "White" immigration with the slave trade stood for the political solution to an economic problem that ultimately followed the movement of reduction implicit in the dualism civilization/barbarity. For just as it is clear that civilization should triumph over barbarity, when it came to population policies it was no secret that salaried laborers from Europe would be given all sorts of incentives to go forth and multiply whereas, slave laborers from Africa were doomed to obsolescence as a sort of endangered animal specie. Openly or not, many colonists knew that there would come a time when the trade in slaves would cease to be. At that moment, many believed and quietly hoped that hard labor would take care of decreasing the number of "Blacks" in the colonies.

By the third decade of the $19^{\text {th }}$ Century some, like the Spanish Creole and proto-nationalist Cuban thinker José Antonio Saco, would posit the future happiness of Cuba as depending on an immediate end to the slave trade and the reduction in the "Black" population. Indeed, Saco unabashedly called for their "extinction, should it be possible" (Saco, 1962, 3: 275). There was no future in Cuba for those he called "morenos", an overarching term that included almost all those who were not "full-blooded" Europeans. In 1837 he argued that all those who fell under that category "can have nothing to do with the politics of nations" (Saco, 1960: 136) and thus were not entitled to be Cuban.

Saco took racist panic to its most extreme revealing the ultimate goal of racialist ideology in a post-plantation society where "Blacks", as slave labor, would no longer be needed. Still, we would argue that the immigration and repopulation policies championed by many as a way of making Cuba a more civilized country through "blanqueamiento" or "social Whitening" were, in the end, pointing in the same direction by justifying a concerted and sustained policy of ethnic cleansing in the name of a "fear of Blacks" that would inform social policy in the island well into the $20^{\text {th }}$ Century and even to this day.

\section{THE TRIUMPH OF CIVILIZATION AS A CRIME AGAINST HUMANITY}

In Cuba, under the guiding principles of enlightened rationalism and always with the Haitian example in the background, there was a renewed interest in knowing and quantifying the makeup of the population along racialized categories: "Whites", slaves/"Blacks" and Free "Colored" people. This was the principal ammunition used by all parties involved in the ideological wars on abolition and repopulation. Many saw these projects as complementary while some believed them to be fully irreconcilable. Then there were those, especially after the start of the wars of independence in 1868 , who fought for the abolition of slavery and the establishment of a republic of equals. They believed in a representative system based on the rule of the majority and were mostly unconcerned by the racialist anxieties of the elites, dismissing the plans for repopulation and "Whitening" for a vision of PanCaribbean unity that found its inspiration in the Louverturian tradition (Buscaglia Salgado, 2011). Along the way, the racialist anxieties that were hidden behind the repopulation plans and promoted through the discourse of the "fear of Blacks" began to be transformed into policy through pseudo-scientific arguments and the interest to shift the debate away from the crude ethnic references to a more refined argument on civilization that would give shape to important trends in Cuban nationalist thought.

Given the contrasting visions on the future of Cuba, either as a "civilized" society or a country of equals, to favor the racialist discourse of "Whitening" and its various projects and policies that came to approach society as a laboratory was to call for the need to avoid at all cost the establishment of what was referred to dismissively as a "Black republic". It is imperative to understand that these were all proposals for repopulation in the face of a "fear of Blacks" that was synonymous with majority rule. Clearly, Cuba was already filled with people most of whom, especially in the ranks of the republican army of Cuba Libre, had no interest in hosting in their country rising numbers of foreigners, especially Spaniards.

Still, official immigration policies and the conditions of slave trading were set in Havana and Madrid by people whose main interest was to increase the happiness of Cuba while avoiding the possibility of it becoming another Haiti (Naranjo, 2009: 21-57). Under that threat, more imagined than real, plans for the repopulation of Cuba were put in motion. Between 1810 and 1850 alone, over one hundred new settlements were created (Pérez de 
la Riva, 2004: 136). New towns and cities reconfigured the landscape and served to regulate social space along spheres of circulation, access and political participation that were strongly conditioned by racialist policies and gender divisions. Guantánamo, Cienfuegos, Nuevitas, Guamacaro, Esperanza, Nueva Paz, Candelaria, Madruga, La Salud, Báez, Manicaragua, Artemisa, Cabañas, Cifuentes, Alacranes, Colón, Manguito, Coralillo, Santo Domingo, Palma Soriano, San José de las Lajas, Cabezas, Caibarién, Rancho Veloz, Mariel, Gíbara, and Manzanillo were some of the settlements built or reconfigured through the introduction of "White" families, especially from the Iberian Peninsula and the Canary Islands, as well as from other parts of Cuba.

This was a period of massive expansion of the plantation, punctuated by the massacre of La Escalera in 1844, a state-sponsored policing action that was meant to strike terror among the "non-Whites" while appeasing the racialist fears of the elites and the new settlers. From then on it became clear that repopulation was an integral piece in the apparatus of social control that, in the name of civilization, aimed to not simply "whiten" Cuba but also to make it more "Spanish". Thus, as far as it was a coordinated set of policies meant to keep Cuba in Spanish hands while generating massive profit for the planters and the Spanish government, it was an integral part of the defense infrastructure and, as such, a weapon of war. Here, Saco's call for the extinction of the "Black" population "if it were possible" (Saco, 1962, 3: 275) came close to achieving its full measure of potentiality in colonial policy. Eventually, repopulation as extermination of the "Blacks" was fully championed by liberals of all kinds in Spain and Cuba under the sanitized version of the discourse that looked at the "White" Spanish settler as the embodiment of civilization and as the only citizen possible in Cuba's quest for happiness. To them it was clear that "the [White] race, among all others, was bestowed with the privilege of ruling over the world." ${ }^{10}$ Cuba would be no exception.

\section{ACKNOWLEDGEMENTS}

This article has been done under the research project with reference number HAR2012-37455-C03-01 (MINECO)

\section{NOTES}

1 The original text reads: "Il ne peut exister d'esclaves sur ce territoire, la servitude y est à jamais abolie. Tous les hommes y naissent, vivent et meurent libres et Français." Quoted in translation in Spanish documents: "En este territorio no pueden subsistir esclavos, la servidumbre está allí abolida para siempre, todos nacen, viven, y mueren libres, y franceses". See Archivo General de Indias (AGI), Estado, 59, n. 17, d. 3: 3 - 4. Henceforth in this article, all translations from the Spanish and French have been made by the authors

2 The Spanish official documents speak of "las ideas del negro Toussaint". AGI, Estado, 65, n. 11.

3 AGI, Estado, 59, n. 14/2/4

4 AGI, Estado, 59, n. 14/1/1

5 AGI, Estado, 59, n. 14/ 1.
6 AGI, Estado, 58, n. 10. See also AGI, Estado, 59, 60, 61, 62, 65 and 66.

7 AGI, Estado, 58, n. 31.

8 AGI, Estado, 59, n. 6/ 6.

9 AGI, Estado, 68, n. 12.

10 "Proyectos de inmigración", El Triunfo, year I, n. 22, Havana, July 26, 1878: 1 .

\section{REFERENCES}

Anonymmous (1806) Vida de J. J. Dessalines, gefe de los negros de Santo Domingo. Con notas muy circustanciadas sobre el origen, carácter y principales atrocidades de los principales gefes de aquellos rebeldes desde el principio de la insurreccion de 1791, D.M.C.G. (trans.), Juan López Cancelada (ed.). Oficina de Mariano de Zúñiga y Ontiveros, Mexico.

Arango y Parreño, Francisco de (1952) Obras. 2 Ts. Dirección de Cultura, Ministerio de Educación, Havana.

Buscaglia Salgado, José F. (2011) "El Caribe al final de la Era Usoniana: Hacia un nuevo modelo de confederación". Aguaita, 23: $38-58$.

Buscaglia Salgado, José F. (2003) Undoing Empire, Race and Nation in the Mulatto Caribbean. University of Minnesota Press, Minneapolis.

Del Monte y Tejada, Antonio (1890) Historia de Santo Domingo. Imprenta de García Hermanos, Santo Domingo.

Dubois, Laurent (2004) Avengers of the New World. The Story of the Haitian Revolution. Harvard University Press, Cambridge.

Dubois, Laurente (2008) "Avenging America. The Politics of Violence in the Haitian Revolution." In The World of the Haitian Revolution, edited by Geggus, David Patrick \& Fiering, Norman. Indiana University Press, Bloomington: 111-124.

Duque de Estrada, Nicolás (2006) Explicación de la doctrina cristiana acomodada a la capacidad de los negros bozales. Biblioteca Nacional José Martí, Havana.

Ferrer, Ada (2004) "Cuba en la sombra de Haití: noticias, sociedad y esclavitud”. In El rumor de Haití en Cuba. Temor, raza y rebeldia, 1789-1844, editado por González-Ripoll, Ma Dolores, Consuelo Naranjo Orovio, Ada Ferrer, Gloria García y Josef Opatrný. CSIC, Madrid: 179-231.

Ferrer, Ada (2015) Freedom's Mirror. Cuba and Haiti in the Age of Revolution. Cambridge University Press, New York.

García, Gloria (2004) "Vertebrando la resistencia: la lucha de los negros contra el sistema esclavista, 1790-1845". In El rumor de Haiti en Cuba. Temor, raza y rebeldía, 1789-1844, editado por González-Ripoll, M ${ }^{\mathrm{a}}$ Dolores, Consuelo Naranjo Orovio, Ada Ferrer, Gloria García y Josef Opatrný. CSIC, Madrid: 233-320.

Garrigus, John (2006) Before Haiti: Race and Citizenship in French Saint-Domingue. Palgrave Macmillan, New York.

Geggus, David, (ed.) (2001) The Impact of the Haitian Revolution in the Atlantic World. University of South Carolina Press, Columbia, S.C.

Geggus, David (2002) Haitian Revolutionary Studies. Indiana University Press, Bloomington.

Geggus, David (2010) "The Caribbean in the Age of Revolution." In The Age of Revolutions in Global Context, c. 1760-1840, edited by Armitage, David and Subramanyam, Sanjay. Palgrave Macmillan, New York: 83-100.

Geggus, David Patrick \& Fiering, Norman (eds.) (2008) The World of the Haitian Revolution. Indiana University Press, Bloomington.

Genovese, Eugene (1979) From Rebellion to Revolution. AfroAmerican Slave Revolts and the Making of the Modern World. Louisiana State University Press, Baton Rouge.

Gomariz, José (2004) "Francisco de Arango y Parreño: El discurso esclavista de la ilustración cubana". Cuban Studies, 35: 45-61.

González-Ripoll, $\mathrm{M}^{\mathrm{a}}$ Dolores (2004) "Desde Cuba, antes y después de Haití: pragmatismo y dilación en el pensamiento de Francisco Arango sobre la esclavitud". In El rumor de Haití en Cuba. Temor, raza y rebeldía, 1789-1844, editado por González-Ripoll, Ma Dolores, Consuelo Naranjo Orovio, Ada Ferrer, Gloria García y Josef Opatrný. CSIC, Madrid: 9-81. 
González-Ripoll, Ma Dolores (2015) "Espejos trucados: la Secret history or the horrors of Santo Domingo (1808), entre la ficción y la historia antillana". Revista de Indias, 263: 93-115.

Lacroix, Pamphile de (1995) "Memoires pour servir à l'histoire de la Révolution de Saint-Domingue." In La Révolution de Haïti, Pierre Pluchon. Karthala, Paris.

Marlés, J. Lacroix de (1845) Histoire descriptive et pittoresque de Saint-Domingue (Haïti). Ad. Mame et Cie., Tours.

Naranjo Orovio, Consuelo (2004) "La amenaza haitiana, un miedo interesado: poder y fomento de la población blanca en Cuba". In El rumor de Haití en Cuba. Temor, raza y rebeldia, 17891844, editado por González-Ripoll, M ${ }^{\mathrm{a}}$ Dolores, Consuelo Naranjo Orovio, Ada Ferrer, Gloria García y Josef Opatrný. CSIC, Madrid: 83-178.

Naranjo Orovio, Consuelo (2009) "Cara y cruz de una política colonial: azúcar y población en Cuba". In Más allá del azúcar: política, diversificación y prácticas económicas en Cuba, 18781930, editado por Santamaría, Antonio y Consuelo Naranjo Orovio. Doce Calles, Aranjuez, Spain: 21-57.

Naranjo Orovio, Consuelo (2013) "La entronización del miedo: iconos del terror y exclusión en el Caribe tras la revolución de Saint-Domingue". In Imaginarios del miedo. Estudios desde la Historia, editado por Ette, Ottmar, Consuelo Naranjo e Ignacio Montero. Edition Tranvia, Berlin: 67-90.
Pérez de la Riva, Juan (2004) La conquista del espacio cubano. Fundación Fernando Ortiz, Havana.

Provine, William B. (1973) "Geneticist and the biology of race crossing." Science, 182: 790-796.

Reiss, Tom (2012) The Black Count: Glory, Revolution, Betrayal, and the Real Count of Monte Cristo. Crown, New York.

Rodríguez Demorizi, Emilio (1955) La era de Francia en Santo Domingo. Editora del Caribe, Ciudad Trujillo (Santo Domingo).

Saco, José Antonio (1962) Colección de Papeles Científicos, Históricos, Políticos y de otros ramos sobre la Isla de Cuba, ya publicados, ya inéditos. 3 tomos. Editora del Consejo Nacional de Cultura, Havana.

Saco, José Antonio (1960) "Examen analítico del informe de la Comisión Especial nombrada por las Cortes sobre la exclusión de los actuales y futuros diputados de Ultramar y sobre la necesidad de regir aquellos países por leyes especiales." In Colección de papeles científicos, históricos, políticos y de otros ramos sobre la Isla de Cuba. Editorial Nacional de Cuba. Havana: 92129

Schoelcher, Victor (1889) Vie de Toussaint Louverture. Paul Ollendorf, Paris.

Sklodowska, Elzbieta (2009) Espejos y espejismos: Haití en el imaginario cubano. Iberoamericana-Vervuert, Madrid-Frankfurt am Main. 